\title{
Landowners' Outlook Towards Soil Erosion Problem and Conservation Strategies in Maksegnit Province, Ethiopia
}

\author{
Kassaye Gurebiyaw", Melese Yigzaw \\ Department of Natural Resources Management, University of Gondar, Gondar, Ethiopia
}

Email address:

kassayegurebiyaw@gmail.com (K. Gurebiyaw)

${ }^{*}$ Corresponding author

\section{To cite this article:}

Kassaye Gurebiyaw, Melese Yigzaw. Landowners' Outlook Towards Soil Erosion Problem and Conservation Strategies in Maksegnit Province, Ethiopia. International Journal of Photochemistry and Photobiology. Vol. 2, No. 1, 2018, pp. 22-27. doi: $10.11648 /$ j.jpp. 20180201.15

Received: July 23, 2018; Accepted: August 9, 2018; Published: September 12, 2018

\begin{abstract}
Soil erosion is an imperative environmental deterioration almost all over the world, which leads to reduction of crop yield. Present study investigates farmers' views of soil erosion problems and their conservation measures in the Gummara-Maksegnit watershed to understand inter-relationships between perception of farmers' knowledge and soil conservation practices. Data was obtained from a survey of 332 farm households and informal discussions selected by stratified random sampling from upper, middle and lower catchment at Fertamit, Enkri and Dilkana districts respectively. Both open ended and close ended questionnaires were employed to acquire required data. The result revealed that $81 \%$ of the local people realize the occurrence of soil erosion in their farm land. Moreover, $67 \%$ of the population recognizes the formation of rill forms of soil erosion on their farm land. $45 \%$ of the communities perceive soil erosion as primary factor for productivity reduction while $48 \%$ of them consider as second cause. Finally, there are several soil conservation measures done by the society living in the watershed. $84 \%$ of the population constructed stone bund on their farm land to control soil erosion. Other soil conservation measures like soil bund, draining ditch, tree planting and contour plowing were practiced. The varieties of conservation measures were very limited and incapable to control erosion forms like gully. Therefore it is highly recommended to teach farmers concerning different soil and water conservation measures and its relevance for tackling soil erosion.
\end{abstract}

Keywords: Farmers' View, Soil Conservation, Soil Erosion, Stratified Random Sampling, Survey

\section{Introduction}

The world has been grappling with how to reconcile the three objectives of increasing agricultural production, reducing poverty and using natural resources sustainably [1]. With the land frontier shrinking due to population pressure, future growth in agriculture will increasingly have to come from yield increases rather than from area expansion [1-2]. Agricultural production shall to increase in such a way that future production capacity of the natural resource is enhanced rather than diminished. Understanding and having effort to control all factors hampering intensive production is highly required in all compartment of the world.

Land degradation is one of the most severe spatial and temporal problems almost all over the world [3-6], which affects $33 \%$ of the land surface; with consequences for more than 2.5 billion peoples livelihood [4]. About $40 \%$ of the world's agricultural land is seriously degraded, where $80 \%$ of this degradation is caused by soil erosion $[4,7,8]$. Each year about 10 million ha of cropland are lost due to soil erosion, thus reducing the soil quality and productive cropland availability for cultivation is being lost from land areas 10 to 40 times faster than the rate of soil renewal imperiling future human food security and environmental quality [9].

Even though land degradation due to soil erosion is a global environmental crisis in this century, the developing and most populated countries are suffering more because of population pressure over land [4, 8, 10-15]. In Ethiopia, one of the developing and second populous countries of the African continent, soil erosion by water constitutes a severe threat to food security $[10,16,17]$. As estimation by prior studies show soil loss due to water erosion is about $149342 \mathrm{Mgha}^{-1}$ per year [18]. The estimated rate of soil loss in the cultivated fields is $42 \mathrm{Mgha}^{-1}$ per year, or $4 \mathrm{~mm}$ of soil depth per annum, which by all measures exceeds the rate of 
soil formation [18]. With this rate of loss, much of the slopes of the highlands, where there is only a thin soil layer, will be totally stripped of the soil mantle in less than two centuries [18].

Soil erosion in northern Ethiopia particularly in Tigray, wollo and Gondar province, is the major challenge of sustainable agriculture [19-21]. It reduces on-farm soil productivity and causes food insecurity [6, 13, 14, 22]. Farmers in the Gummara-Maksegnit watershed (North Gondar, Ethiopia) suffer from severe soil erosion ranging from small rills to very large gullies and their deleterious effects increase at alarming rate. Farmers are not satisfied with the status of their current land productivity.

An attempt of soil and water conservation (SWC) work in Ethiopia was started sicnce1970 [16]. Thereafter, to overcome the problem of land degradation, the government has implemented soil conservation activities, such as construction of physical structures (terraces) to reduce overland flow thereby preventing removal of soil, soil fertility improvement practices (compost application), agroforestry and reforestation of deforested hilly areas.

Effective control of soil erosion is a critical component of natural resource management when the aim is to achieve sustainable agriculture and acceptable ecosystem integrity $[10,17]$. Farmers' perception of land degradation by erosion is a key social factor that is also important in deciding options for controlling soil losses [9, 10, 17, 23]. Some authors who studied in different parts of Ethiopian highlands reported that farmers are more likely to adopt conservation measures in plots that are highly prone to soil erosion, such as plots where slopes are steep and erosion features are visible [8, 10, 14, 17, 19, 24-28]. Farmers rather frequently reject newly introduced soil and water conservation technologies (SWC) even when they are aware that the measure protect and improves productivity of their lands [17, $19,26]$. Based on the literature cited above, it is obvious that the newly introduced SWC technologies need to be evaluated not only for their technical efficacy but also for the probability of their sustainable adoption and utilization by the land users. It requires identification of barriers to and facilitators of adoption of the technologies. Once the barriers and facilitators are identified, recommendations can be made on appropriate steps that need to be taken to enhance the adoption of the technologies and to effect sustainable land use.

Understanding farmers' knowledge and their perception and factors that influence their land management practices are of paramount importance for promoting sustainable land management $[1,2,4,7,28]$. We attempted to understand farmers' knowledge and perception on soil erosion processes, soil fertility, acceptance and adoption of the newly introduced soil and water conservation (SWC) measures and other relevant data used for the study. The specific objectives of this research are (1) to understand the farmers' perception and awareness of erosion processes and SWC measures as a land management practice; (2) to examine the local farmers' acceptance and adoption of land conservation technologies; and (3) to identify factors affecting their land conservation decisions.

\section{Description of the Study Area}

The study area is Gummara-Maksegnit watershed which is located in the eastern part of Amhara Region of Ethiopia. This mountainous agricultural watershed, which covers an area of $63 \mathrm{~km}^{2}$, is one of the most severely eroded parts of the Ethiopian highland. The study watershed has a very rugged mountainous topography, with an average slope of $21 \%$ and most of the study watershed is composed of gullies and ridges. The soil types of the watershed are predominately classified as Nitosols, which covered in the upper and central part of the area, while Vertisols in the lower parts of the watershed near the outlet. The common land use types of the watershed are mainly agricultural (crop) land, forest land and grazing land. The Gummara-Maksegnit watershed has three district and detail characteristics of each study village are explained in table1.

Table 1. Major bio-physical and socio-economic characteristic of three districts in the Maksegnit watershed [29].

\begin{tabular}{|c|c|c|c|}
\hline Characteristics of Districts & Fertamit (Upper stream) & Enkri (Middle stream) & Dilkana (Lower stream) \\
\hline Area (ha) & 520,000 & 456,000 & 542,000 \\
\hline Topography & Steep to very steep & Moderately steep to flat & Fairly flat \\
\hline Mean elevation (m) & 2001 & 1600 & 988 \\
\hline Annual rainfall (mm) & 1958 & 1844 & 1832 \\
\hline Temperature $\left({ }^{\circ} \mathrm{C}\right)$ & Max. $32^{\circ} \mathrm{C}$, Min. $21^{\circ} \mathrm{C}$ & $\operatorname{Max} .33^{\circ} \mathrm{C}, \operatorname{Min} .23^{\circ} \mathrm{C}$ & $\operatorname{Max} .35^{\circ} \mathrm{C}, \operatorname{Min} .22^{\circ} \mathrm{C}$ \\
\hline Agricultural Land (\%) & 65 & 59 & 72 \\
\hline Area under soil erosion by water $(\%)$ & 54 & 32 & 22 \\
\hline Major soil erosion process & Rill, gullies & Sheet, rill and gullies & Sheet and rill erosion \\
\hline Farming system & Multiple crops & Multiple crops & Multiple crops \\
\hline Major crops' grown & Barley, pea and wheat & Wheat, barley and teff & Wheat and teff \\
\hline Fertility status & Very low & Moderate & Moderate- high \\
\hline Food Security condition & Insecure & Insecure & Partially secure \\
\hline Average land size per households (ha) & 0.25 & 0.88 & 0.90 \\
\hline Total number of farmers & 92,700 & 88,400 & 82,750 \\
\hline Dominant tree species & Numerous native species & Numerous native species & Numerous native species \\
\hline
\end{tabular}




\section{Research Methods}

A total of 332 farm households were randomly selected from the three villages (Fertamit, Enkri and Dilkana) for interviews. A detailed characteristic of the sample households of the study is presented in Table 2. The data was collected during the period between January and May 2018. This study period was selected purposively as it corresponds to maximum agricultural activities of that province.

Socioeconomic data collection methods like questionnaires, key informants interview, focus group discussion and observation was employed to acquire necessary data. The questionnaire used in the present study is consisted of both the closed and open-ended questions. However, the most of the questionnaires were open-ended thus providing respondents with a prospect to convey their outlooks without being constrained by pre-determined reaction. The key issues incorporated in the questionnaire were farmers' perception of erosion occurrence, extent and impact, changes in soil fertility and yielding properties of land, and knowledge of soil conservation.

Preliminary survey was conducted for a couple of objectives. The first one is just to verify the presence of soil erosion problem and secondly to train data collectors. Basic information on household size and farming practices constituted the closed type of question. Issues regarding soil degradation and soil conservation practices were put in open question format. The respondents were encouraged to mention as many indicators, reasons and practices as possible.

Total 332 households' characteristics were grouped in three classes based on knowledge of soil erosion and soil water conservation (Table 3 ), because perception of farmers about soil erosion problem and attempts done to control soil erosion are quite different among inhabitants. Microsoft excel software were used to analyze the data. Descriptive statistics was employed to summarize the data.

Table 1. The study villages of Maksegnit watershed and proportional sample size.

\begin{tabular}{lllll}
\hline Watershed & Catchments & Districts & Study villages & Samples size (households) (n) \\
\hline \multirow{3}{*}{ Maksegnit } & Upper & Fertamit & 11 & 118 \\
& Middle & Enkri & 8 & 105 \\
Total & Lower & Dilkana & 9 & 109 \\
\hline
\end{tabular}

\section{Results and Discussion}

\subsection{Household and Farm Characteristics}

The age of the farmers ranged between 18 and 73 years. In the study area $11 \%$ households were female headed and $78 \%$ were uneducated and $22 \%$ were literate as per the agricultural bureau report indicate in 2017. Literacy rates among the investigated villages varied according to distance from city center of the province.

The land properties size of the respondent families varied between 0.25 hectares and 3.0 hectares, with an average holding size of about 1.625 hectares. $72 \%$ households were stated that the size of land holdings were progressively more insufficient to support their households. It is due to mainly the growth of rural population. In the province, whenever any child aged eighteen they obliged families to share the land. The remaining land failed to support house heads and below eighteen age children. Households are cultivating their small land year to year without any rest period. Thus land degradation is being worse due to continuous cultivation.

\subsection{Farmers View Regarding Cause and Effects of Soil Erosion}

The farmers of the Gummara-Maksegnit watershed experience decrement of crop production for the last four decades. Since, the all time severe drought caused famine in 1984; inhabitants are disgusted by their low crop production. More than $84 \%$ of the farmers realize the occurrence of soil erosion on their farm land (Table 3). Soil erosion level mentioned by the farmers included loss of topsoil (sheet erosion), development of small rills, sedimentation in depression area (lower slope) and flood having soil color. In addition they already know the occurrence of gullies, which are the most dangerous forms of soil erosion. Former studies in Ethiopia showed that the occurrence of soil erosion in different form at different district of the country [2, 10, 17].

Table 3. Extent of soil erosion problems, types and its impact and change over time.

\begin{tabular}{lllll}
\hline \multirow{2}{*}{ Farmers' responses to: } & Fertamit & Enkri & Dilkana & Total \\
\cline { 2 - 5 } & $(\mathbf{n = 1 0 9 )}$ & $(\mathbf{n = 1 0 5})$ & $(\mathbf{n = 1 1 8})$ & $\mathbf{( n = 3 3 2 )}$ \\
\hline Erosion faced in own farm & & & & \\
Yes (\%) & 79 & 81 & 83 & 81 \\
No (\%) & 22 & 17 & 18 & 19 \\
Forms of erosion in own farm & & & & \\
Sheet erosion (\%) & 24 & 22 & 26 & 24 \\
Rill erosion (\%) & 62 & 68 & 71 & 67 \\
Gully erosion (\%) & 3 & 2 & 5 & 8 \\
Severity of soil erosion & & & & \\
Severe (\%) & 63 & 69 & 72 & 68 \\
Moderate (\%) & 23 & 19 & 24 & 22 \\
Slight (\%) & 13 & 10 & 7 & 10 \\
Impact of erosion on crop yield & & & & \\
Severe (\%) & 60 & 69 & 72 & 67 \\
Moderate (\%) & 20 & 16 & 21 & 19 \\
Minor (\%) & 17 & 14 & 11 & 14 \\
Temporal change of soil erosion & & & & \\
Increasing (\%) & 59 & 67 & 69 & 65 \\
Same (\%) & 25 & 21 & 23 & 23 \\
Decreasing (\%) & 14 & 12 & 10 & 12 \\
\hline
\end{tabular}


Almost half of the land owners (51\%) revealed that high rainfall is the main factors of soil erosion. And $34 \%$ of the local people consider steep slopes as the second contributor of soil erosion. Local people also stated that ecosystem disturbance during constructions like road and building were additional causes of soil erosion. As it is checked during field verification very huge soil is dumped just near to rivers.

Farmers reported that they observed decline in land productivity, loss of fertile soil, shortage of farm and grazing land, loss of seeds and increasing fertilizer requirements. They realize the formation of gullies that inhibit agricultural activities, mobility of people and cattle, exposure of hard subsoil layers as the consequence of soil erosion. People also realized the pollution of aquatic ecosystem by chemicals and soil particles transported from farm land. A number of small seas in the watershed had changed their color due to deposition of soil particle.

Table 4. Causes of soil erosion, soil fertility status and temporal changes of soil fertility.

\begin{tabular}{|c|c|c|c|c|}
\hline \multirow{2}{*}{ Farmers' responses to: } & Fertamit & Enkri & Dilkana & Total \\
\hline & $(n=109)$ & $(n=105)$ & $(n=118)$ & $(n=332)$ \\
\hline \multicolumn{5}{|l|}{ Causes of soil erosion } \\
\hline Erosive rains $(\%)$ & 51 & 49 & 53 & 51 \\
\hline Slope steepness $(\%)$ & 25 & 37 & 40 & 34 \\
\hline Others $(\%)$ & 17 & 13 & 15 & 15 \\
\hline \multicolumn{5}{|l|}{ Causes of productivity decline } \\
\hline Soil erosion $(\%)$ & 42 & 46 & 47 & 45 \\
\hline Others $(\%)$ & 7 & 5 & 9 & 7 \\
\hline \multicolumn{5}{|l|}{ Soil fertility status in own plots } \\
\hline High fertility $(\%)$ & 15 & 12 & 9 & 12 \\
\hline Medium fertility (\%) & 44 & 43 & 39 & 42 \\
\hline Poor fertility $(\%)$ & 49 & 44 & 45 & 46 \\
\hline \multicolumn{5}{|c|}{ Changes in soil fertility in past decade } \\
\hline Declining (\%) & 60 & 65 & 67 & 64 \\
\hline No change $(\%)$ & 22 & 21 & 26 & 23 \\
\hline
\end{tabular}

\subsection{Soil Fertility Status and Temporal Changes}

Local people reported that soil fertility status is poor and decreasing from time to time. $46 \%$ farmers in the study site stated that their plots having a poor level of soil fertility while $42 \%$ respondents considered for medium soil fertility.
The remaining $12 \%$ of the people consider their farm as high fertile; probably their land is located at depression where sedimentation from upper land is happen. $64 \%$ of the cultivators observed decrement of soil fertility in the past ten years.

Table 2. Different soil and water conservation measures adopted.

\begin{tabular}{|c|c|c|c|c|}
\hline \multirow{2}{*}{ Farmers' response to: } & Fertamit & Enkri & Dilkana & Total \\
\hline & $(n=109)$ & $(n=105)$ & $(n=118)$ & $(n=332)$ \\
\hline \multicolumn{5}{|l|}{ Type of SWC measure } \\
\hline Yes $(\%)$ & 86 & 84 & 82 & 84 \\
\hline No $(\%)$ & 19 & 16 & 13 & 16 \\
\hline \multicolumn{5}{|l|}{ Contour plowing } \\
\hline No $(\%)$ & 14 & 16 & 15 & 15 \\
\hline \multicolumn{5}{|l|}{ Drainage ditches } \\
\hline Yes $(\%)$ & 71 & 73 & 78 & 74 \\
\hline No $(\%)$ & 29 & 24 & 25 & 26 \\
\hline \multicolumn{5}{|l|}{ Tree planting } \\
\hline Yes $(\%)$ & 82 & 78 & 80 & 80 \\
\hline \multicolumn{5}{|l|}{ Soil bunds } \\
\hline Yes $(\%)$ & 83 & 84 & 82 & 83 \\
\hline No $(\%)$ & 14 & 16 & 21 & 17 \\
\hline
\end{tabular}

\subsection{Use of Soil and Water Conservation Technologies}

Water erosion control measures are land management practices that control run-off or run-on. Soil and stone bunds are the introduced techniques which can be used alternatively based on the availability of stones and labor. The survey 
showed that, $83 \%$ of households constructed soil bunds in at least one of their plots to counter water erosion. $84 \%$ of the community used to practice stone bund to tackle soil erosion. Construction of stone and soil bund is different from village to village. Stone bunds were highly used in upper stream where plenty of stone is available. The middle and lower stream of the watershed are practicing soil bunds. But several individual realize that conservation works are not enough.

\section{Conclusion}

The study assesses the farmers' perception and management strategy in relation to soil erosion problem in three districts- Fertamit, Enkri and Dilkana of GummaraMaksegnit watershed. The study revealed that farmers in the study area are well aware of the soil erosion problem and its positive and negative impacts. They have faced soil erosion in their plots of land decades ago and soil erosion problem is being worse from time to time. This study also revealed that farmers have a holistic observation of soil erosion and turning down of productiveness as the consequence. Cultivators had superior information on soil wearing away, management, and productiveness enhancement methods. Consequently, building on farmers' knowledge via participatory resource management strategy is crucial and government should testify the appropriateness and simplicity of newly induced soil and water conservation technologies.

In conclusion, Study results suggest that policies should encourage formation of grass roots organizations such as farmer groups and community team. This will improve social capital amongst farmers. Farmer to farmer learning should be applied to enhance adoption of new technologies. It is also necessary to enhance farmer education, and increase extension outreach in order to disseminate information on new technologies and to raise awareness. Then, the adoption and use of soil and water technologies will be enhanced and sustained.

\section{Acknowledgements}

We thank university of Gondar for funding this research work. And also we have great respect and appreciation for agricultural extension office staff for their collaboration during data collection.

\section{References}

[1] B. Gebremedhin and S. M. Swinton, "land tenure security and public programs," vol. 29, pp. 69-84, 2003.

[2] P. Asrat, K. Belay, and D. Hamito, "Determinants of farmers ' willingness to pay for soil conservation practices in the southeastern highlands of ethiopia," vol. 438, pp. 423-438, 2004.

[3] W. Sun, Q. Shao, J. Liu, and J. Zhai, "Assessing the effects of land use and topography on soil erosion on the Loess Plateau in China," Catena, vol. 121, pp. 151-163, 2014.

[4] Y. Kassa, "Impact of Integrated Soil and Water Conservation
Program on Crop Production and Income in West Harerghe Zone, Ethiopia," International Journal of Environmental Monitoring and Analysis, vol. 1, no. 4, p. 111, 2013.

[5] S. U. Baba, "Farmers ' Perceptions of Soil Degradation in Rural Kano, Northern Nigeria," vol. 7, no. 1, pp. 8-12, 2017.

[6] D. M. Moges and A. A. Taye, "Determinants of farmers' perception to invest in soil and water conservation technologies in the North-Western Highlands of Ethiopia," International Soil and Water Conservation Research, vol. 5, no. 1, pp. 56-61, 2017.

[7] P. L. G. Vlek and M. Denich, "Ecology and Development Series No. 89, 2012 Effectiveness of soil and water conservation measures for land restoration in the Wello area, northern Ethiopian highlands," no. 89, 2012.

[8] D. Weldemariam, M. Kebede, M. Taddesse, and T. Gebre, 'Farmers' perceptions' and participation on Mechanical soil and water conservation techniques in Kembata Tembaro Zone: the Case of Kachabirra Woreda, Ethiopia," International Journal of Advanced Structures and Geotechnical Engineering, vol. 02, no. 04, pp. 2319-5347, 2013.

[9] D. Pimentel and M. Burgess, "Soil Erosion Threatens Food Production," Agriculture, vol. 3, no. 3, pp. 443-463, 2013.

[10] K. K. Beyene, "Soil Erosion, Deforestation and Rural Livelihoods in Thecentral Rift Valley Area of Ethiopia: a Case Study in the Denku Micro- Watershed Oromia Region," p. 90, 2011.

[11] A. Negassi, E. Bein, and K. Gebru, Soil conservation Some case studies, no. 23. 2000.

[12] Y. Gebreselassie, T. Amdemariam, M. Haile, and C. Yamoah, "Lessons from upstream soil conservation measures to mitigate soil erosion and its impact on upstream and downstream users of the Nile River," CP 19 Project Workshop Proceedings, pp. 170-183, 2009.

[13] J. Nyssen, K. Descheemaeker, M. Haile, J. Deckers, and J. Poesen, Lessons learnt from 10 years research on soil erosion and soil and water conservation in Tigray. Tigray Livelihood Papers No. 7, no. 7. 2007.

[14] A. Birhanu and D. Meseret, "Structural Soil and Water Conservation Practices in Farta District, North Western Ethiopia: An Investigation on Factors Influencing Continued Use," vol. 7522, no. 4, pp. 114-121, 2013.

[15] A. Ayalew, "Construction of Soil Conservation Structures for improvement of crops and soil productivity in the Southern," vol. 1, no. 1, pp. 21-29, 2011.

[16] K. Herweg and E. Ludi, "The performance of selected soil and water conservation measures - case studies from Ethiopia and Eritrea," 1999.

[17] A. D. Zegeye, "Assessment of upland erosion processes and farmer's perception of land conservation in Debre-Mewi watershed, near Lake Tana, Ethiopia," Perception, p. 90, 2009.

[18] H. Hurni, "Land degradation, famine, and land resource scenarios in Ethiopia," Cambridge University Press, Cambridge, pp. 27-62, 1993.

[19] A. Adugna, A. Abegaz, and A. Cerdà, "Soil erosion assessment and control in Northeast Wollega, Ethiopia," Solid Earth Discussions, vol. 7, no. 4, pp. 3511-3540, 2015. 
[20] D. Meseret, "Land Degradation in Amhara Region of Ethiopia: Review on Extent, Impacts and Rehabilitation Practices," vol. 6, no. 1, pp. 120-130, 2016.

[21] T. Gashaw, A. Bantider, and H. G. Silassie, "Land Degradation in Ethiopia: Causes, Impacts and Rehabilitation Techniques," vol. 4, no. 9, pp. 98-105, 2014.

[22] J. Dumanski, "Evolving concepts and opportunities in soil conservation," International Soil and Water Conservation Research, vol. 3, no. 1, pp. 1-14, 2015.

[23] W. Zhi, H. Lang, Z. Min, and J. Li, "Soil degradation and restoration as affected by land use change in the semiarid Bashang area, northern China," vol. 59, pp. 173-186, 2005.

[24] S. Thiemann, "Assessment of Erosion and Soil Erosion Processes - a Case Study from the Northern Ethiopian Highland," vol. 3, pp. 173-185, 2005.
[25] G. Grabherr, "Biodiversity in the high ranges of the Alps: Ethnobotanical and climate change perspectives," Global Environmental Change, vol. 19, no. 2, pp. 167-172, 2009.

[26] A. Amsalu and J. De Graaff, "Determinants of adoption and continued use of stone terraces for soil and water conservation in an Ethiopian highland watershed," vol. 1, 2006.

[27] K. Esser and M. Haile, "Soil Conservation in Tigray, Ethiopia,” Soil Conservation, no. 5, pp. 1-21, 2002.

[28] H. Teklewold and G. Kohlin, "Risk preferences as determinants of soil conservation decisions in Ethiopia," Journal of Soil and Water Conservation, vol. 66, no. 2, pp. 87-96, 2011.

[29] WARDO, "Socio-economic inventory of admistrative regions," 2017. 